\title{
The Effectiveness of the Android-Based Calistung Digital Game Application to Improve Early Childhood Cognitive Skills
}

\author{
Evi Selva Nirwana ${ }^{1}$
}

DOI: $10.35445 /$ alishlah.v13i1.435

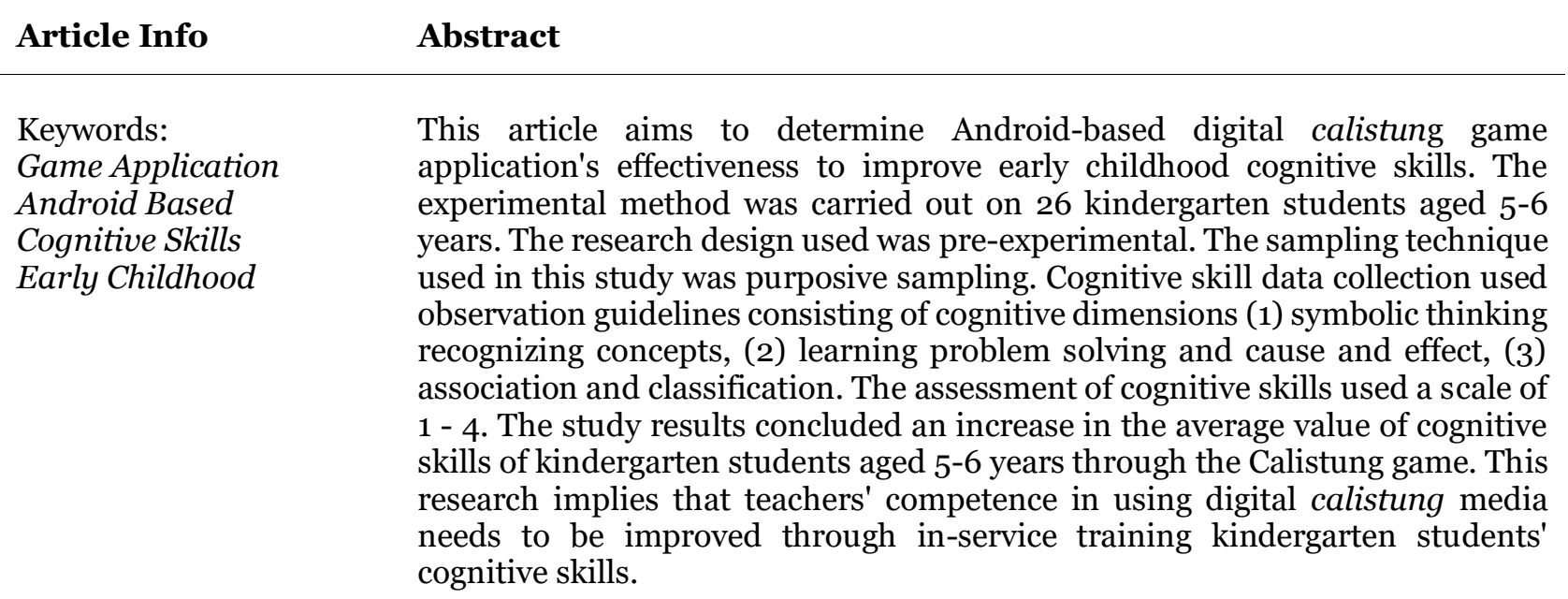

Kata kunci:

Aplikasi Game

Berbasis Android

Keterampssilan Kognitif

Anak Usia Dini

\begin{abstract}
Abstrak
Artikel ini bertujuan untuk mengetahui efektifitas aplikasi game calistung digital berbasis android untuk meningkatkan keterampilan kognitif anak usia dini. Metode eksperimen dilakukan pada 26 siswa taman kanak-kanak usia $5-$ 6 tahun. Desain penelitian yang digunakan adalah pre-eksperimental design. Teknik sampling yang digunakan dalam penelitian ini purposive sampling. Pengumpulan data keterampilan kognitif menggunakan pedoman observasi yang terdiri dari dimensi kognitif (1) berpikir simbolik mengenal konsep, (2) belajar pemecahan masalah dan sebab akibat, (3) asosiasi dan klasifikasi. Penilaian keterampilan kognitif menggunakan skala 1 - 4. Hasil penelitian menyimpulkan bahwa terdapat peningkatan nilai rata-rata keterampilan kognitif siswa taman kanak-kanak usia 5-6 tahun melalui game calistung. Implikasi dari penelitian ini bahwa kompetensi guru dalam menggunakan media calistung digital perlu ditingkatkan melalui inservice training sebagai upaya untuk meningkatkan keterampilan kognitif siswa taman kanak-kanak.
\end{abstract}

\section{PENDAHULUAN}

Siswa saat ini merupakan generasi pertama yang tumbuh dalam dunia digital (Smaldino, Lowther, dan Russell, 2012). Ponsel, pemutar DVD portabel, permainan komputer, instant messaging, dan iPod merupakan perangkat sehari-hari. Siswa semacam ini dikenal dengan digital

\footnotetext{
${ }^{1}$ Institut Agama Islam Negeri Bengkulu, Indonesia

Email: eviselvanirwana@iainbengkulu.ac.id
} 
natives (Smaldino, Sharon E; Lowther, Deborah L; Russell, 2012, p. p.12). Tantangan sekolah adalah menciptakan lingkungan pendidikan yang melampaui dan meningkatkan kemampuan digital natives. Perubahan-perubahan itu akan berdampak pada teknologi masa depan yang digunakan oleh guru dan siswa, struktur ruang kelas, dan peran guru.

Berbagai penelitian menyimpulkan bahwa game digital berbasis kognitif secara efektif dapat meningkatkan kemampuan spasial peserta didik (Lin \& Chen, 2016), mampu menghibur pemain (Kurniati, Tanzil, \& Purnomo, 2015), memberikan implikasi ke dalam kelas menulis, dapat meningkatkan kemampuan dan motivasi belajar bahasa (Udjaja, Tanuwijaya, \& Kartika, 2019). Teknologi game cocok untuk mendukung peningkatan dan pengembangan kapasitas anak (Nacher, Garcia-sanjuan, \& Jaen, 2016). Permainan digital berfungsi sebagai alat pendidikan yang berguna dan dapat berkontrbusi pada proses pembelajaran anak, cara di mana anak-anak kecil berkolaborasi saat bermain game (Kokkalia, Georgia; Economou, Alexandra; Choli, 2017). Terdapat beberapa aplikasi yang dapat digunakan dalam keterampilan melek huruf awal (Northrop \& Killeen, 2013). Penelitian Putro, Kurniawati dan Angkoso mengimplementasikan game edukasi matematika dasar yang diintegrasikan pada aplikasi maze pada perangkat mobile berbasis android (Nasional \& Informasi, 2014). Penelitian Priantoro, Hendrawan, dan Kurniawati (Nasional \& Informasi, 2014) mengembangkan game edukasi pada mobile phone dalam belajar matematika dasar. Penelitian Shohib (Nasional \& Informasi, 2014) mengembangkan rancang bangun game Alena untuk pembelajaran baca tulis yang disisipkan bahasa Madura berbasis mobile android. Penelitian Park (Park, 2013) menunjukkan bahwa aktivasi gabungan memiliki efek yang secara signifikan lebih positif pada pemahaman peserta tentang konsep angka terutama seriasi dan penambahan daripada aktivitas tradisional.

Dari beberapa penelitian lima tahun terakhir dapat disimpulkan bahwa kajian ini berbeda dengan penelitian sebelumnya karena akan membahas mengenai media aplikasi game calistung digital berbasis android yang efektif untuk meningkatkan keterampilan kognitif anak usia 5-6 tahun. Dimensi kognitif yang mengalami peningkatan pada anak usia 5-6 tahun antara lain berpikir simbolik dan mengenal konsep, belajar pemecahan masalah dan sebab akibat, asosiasi, klasifikasi dan aplikasi game calistung digital dibangun degan menggunakan aplikasi unity 3D.

Aplikasi unity 3D adalah software game engine yang digunakan untuk membuat game. Saat ini Unity sudah mendukung berbagai format file seperti gambar, video, music, objek 3D dan lainlain, sehingga sangat memudahkan pengembang dalam pembuatan sebuah game. Unity merupakan game engine multiplatform. Unity mampu di publikasikan menjadi Standalone (.exe), berbasis web (WebGL), Android (.apk), IoS Iphone, XBOX, PS3 dan lain-lain. Dalam pembuatan game calistung ini, unity versi tidak berbayar sudah cukup untuk digunakan. Untuk mengaktifkan lisensi free cukup dengan mendaftarkan email di website unity. Email yang telah didaftarkan dapat digunakan untuk login saat aktivasi.

Perkembangan kognitif anak-anak prasekolah terkait dengan bagaimana kemampuan berpikir mereka berkembang. Bagi Piaget, perkembangan kognitif anak berasal dari kematangan biologis, interaksi mereka dengan lingkungan dan temuan spontan mereka tentang hal. Piaget membagi pengetahuan anak ke dalam tiga kategori pertama pengetahuan fisik, kedua pengetahuan logis matematis, dan ketiga pengetahuan sosial (Beaty, 2013, pp. 268-270). Lebih lanjut dijelaskan bahwa (1) Pengetahuan fisik dimana anak-anak belajar tentang objek dilingkungan mereka secara fisik memanifulasi objek. Mereka mulai menyusun konsep mental tentang bentuk, ukuran, dan warna dari objek, (2) pengetahuan logis - matematis dimana anak-anak menyusun hubungan tentang benda-benda seperti sama dan berbeda, lebih dan kurang, mana yang sekelompok, berapa banyak, seberapa banyak, (3) pengetahuan sosial dimana anak-anak mempelajari aturan bagi perilaku dan pengetahuan tentang tindakan orang-orang lewat keterlibatan mereka dengan orangorang.

Proses-proses yang digunakan anak saat mereka membangun pengetahuan tentang dunia menurut Piaget meliputi skema, asimilasi, akomodasi, organisasi, keseimbangan dan 
penyeimbangan (Santrock, John W Diterjemahkan Oleh Rachmawati, Mila dan Kuswanti, 2007). Hasil dari proses ini menurut Piaget (Morrison, George S., 2012) adalah individu-individu mengalami empat tahap perkembangan. Piaget yakin ada empat tahapan perkembangan kognitif antara lain (1) sensorimotor, (2) praoprasional, (3) oprasional konkret, (4) oprasional formal.

Vygotsky dalam Santrock mengatakan bahwa perkembangan kognitif dan bahasa anak-anak tidak berkembang dalam suatu situasi sosial yang hampa (Santrock, 2002). Maka Vygotsky mengenalkan konsep mengenai zona perkembangan proximal (zone of proximal development). ZPD ialah istilah Vygotsky untuk tugas-tugas yang terlalu sulit untuk dikuasai sendiri oleh anak-anak, tetapi dapat dikuasi dengan bimbingan dan bantuan dari orang-orang dewasa atau anak-anak yang lebih terampil. Penekanan Vygotsky pada ZPD menegaskan keyakinannya tentang pentingnya pengaruh-pengaruh sosial terhadap perkembangan kognitif dan peran pengajaran dalam perkembangan anak. Vygotsky meyakini bahwa perkembangan kognitif terjadi lewat interaksi anak dengan orang lain yang lebih kompeten, guru, teman sebagaya, orang tua yang bertindak sebagai pemandu, fasilitar dan pelatih untuk membrikan dukungan yang dibutuhkan anak untuk dapat berkembang secara intelektual.

Catron dan Allen membagi aspek perkembangan menjadi 6 ranah perkembangan yaitu (1) kesadaran pribadi, (2) emosi, (3) sosialisasi, (4) komunikasi, (5) kognitif, (6) persepsi motoric. Aspek kesadaran (Catron, Carol E \& Allen, 1999). Aspek kognitif juga terbagi menjadi 4 yaitu (a) pemecahan masalah dan sebab akibat, (b) formasi konsep, (c) meniru dan ingatan, (d) asosiasi dan klasifikasi. Perkembangan aspek kelima adalah kognitif bagi anak umur 5-6 tahun menurut Catron dan Allen meliputi (a) menamai 4 warna, (b) menghitung 10 benda, (c) mengidentifikasi 8 warna dan Namanya, (d) mengidentifikasi bentuk persegi, (e) mengembangkan urutan kejadian yang logis, (f) mengidentifikasi objek di 'tengah', (g) mendeskripsikan cuaca, (h) menghitung 13 benda, (i) menyusun benda dari kecil ke besar, (j) menunjukkan benda yang lebih besar, (k) mencoba cara lain untuk memecahkan masalah teman sebaya.

Allen dan Marotz menjelaskan perkembangan perseptual kognitif anak usia lima tahun adalah (1) membentuk segiempat dari dua potongan segitiga, (2) membangun undakan dari balok-balok kecil, (3) mengerti dan menunjukkan konsep berbentuk dan berukuran sama, (4) mengelompokkan benda dengan dua dasar kategori misalnya warna dan bentuk, (5) mengelompokkan bermacammacam benda sehingga semua benda dalam satu kelompok mempunyai satau persamaan (keterampilan mengelompokkan semua makanan atau kapal atau binatng), (6) mengerti konsep terkecil dan terpendek dengan menempatkan benda dari yang terpendek sampai yang tertinggi, terkecil sampai terbesar, (7) menyebutkan benda dengan urutan letak tertentu seperti pertama, kedua, terakhir, (8) berhitung dengan mengeluarkan suara sampai angka 20 dan lebih, (9) mengenali angka dari 1 - 10, (10) memahami konsep lebih banyak - sedikit, (11) memahami istilah gelap, terang dan awal, (12) menghubungkan jam dengan jadwal sehari-hari, (13) mengetahui kegunaan kalender, (14) mengenali dan bisa menyebutkan satuan uang, (15) memahami huruf seperti dapat menyebutkan huruf kecil dan huruf besar, (16) memhami konsep setengan seperti bisa menyebutkan bagian yang tersisa bila sebuah benda sudah diiris setengah, (17) menggunakan kata Mengapa? Apa? Dimana? Kapan?, (18) ingin balajar banyak hal baru (Allen, K Eileen: Marotz, 2010, p. 151).

Pendapat lain dikemukakan oleh Janice $J$ Beaty yang membuat daftar perkembangan untuk usia anak 3 sampai 5 tahun yang dibagi menjadi 6 ranah, yaitu: (1) emosional, (2) sosial, (3) fisik, (4) kognitif (5) bahasa, (6) kreatif (Beaty, 2013). Perkembangan kognitif, menurut Beaty meliputi (a) memilah objek berdasarkan bentuk dan warna, (b) mengelompokkan objek berdasarkan ukuran, (c) menempatkan objek dalam urutan atau rangkaian tertentu, (d) mengenali dan membuat pola, (e) menghitung sambil menghafal 1 hingga 20, (f) menampikan korespondensi satu satu dengan 
angka, (g) menyelesaikan soal dengan benda konkret, (h) menyelesaikan masalah dengan program komputer.

Seefeldt \& Barbour dalam Morrow menyebutkan tahapan perkembangan anak untuk usia 5 6 tahun antara lain (a) fisik, (b) sosial, (c) emosional, (d) kognitif (Morrow, 1993, pp. 34-35). Perkembangan kognitif yaitu (1) mulai mengenali konservasi jumlah dan panjang, (2) menjadi tertarik pada huruf dan angka, (3) Dapat mulai mencetak atau menyalin huruf dan angka, (4) hitungan, (5) tahu sebagaian besar warna, (6) mengakui bahwa seseorang bisa mendapatkan makna dari kata-kata yang ditulis, (7) Mengetahui waktu, (8) tahu nama hari.ari bebe

Penelitian ini sangat penting dilakukan mengingat dari beberapa hasil penelitian menjelaskan pentingnya media digital salah satunya aplikasi android dapat meningkatkan keterampilan kognitif, literasi, kemampuan spasial, kemampuan dan motivasi belajar bahasa, menghibur pemain, belajar angka, belajar menulis, keterampilan memahami huruf awal, matematika dasar. Tantangan sekolah adalah menciptakan lingkungan pendidikan yang meningkatkan kemampuan digital natives siswa sehingga dapat mengembangkan kemampuan pada aspek yang lainnya seperti aspek perkembangan kognitif, bahasa, seni, nilai agama dan moral, sosial emosional.

\section{METODE}

Metode yang digunakan dalam penelitian ini adalah metode eksperimen yang bertujuan untuk menguji efektifitas aplikasi berbasis android untuk meningkatkan keterampilan kognitif anak usia 5 - 6 tahun di Taman Kanak-kanak. Desain penelitian menggunakan pre-eksperimental design artinya menggunakan seluruh subjek dalam kelompok belajar untuk diberikan perlakuan tapi bukan menggunakan subjek yang diambil secara acak. Bentuk desain yang digunakan dalam penelitian ini yaitu one group pretest - posttest design. Dapat digambarkan sebagai berikut:

Keterangan:

\begin{tabular}{|ll|}
\hline $\mathrm{O} 1$ & $\mathrm{X} 2$ \\
\hline
\end{tabular}

\begin{tabular}{|l|l|l|}
\hline O1 & $:$ & Nilai pretest (sebelum diberi perlakuan \\
\hline O2 & $:$ & Nilai posttest (sesudah diberi perlakuan \\
\hline
\end{tabular}

Populasi penelitian ini adalah siswa taman kanak-kanak berusia $5-6$ tahun di kecamatan Ciputat Timur, kota Tangerang Selatan, provinsi Banten, Indonesia. Teknik sampling yang digunakan dalam penelitian ini adalah purposive sampling dengan Teknik pengambilan sampel sumber data dengan pertimbangan tertentu. Sampel dalam penelitian ini menggunakan dua TK, yaitu TK Melati yang berjumlah 10 siswa usia 5- 6 tahun dan TK Mentari yang berjumlah 16 siswa usia 5 - 6 tahun. Jumlah sampel secara keseluruhan adalah 26 siswa TK usia $5-6$ tahun. Arikunto (2013) menjelaskan bahwa instrument penelitian merupakan alat untuk mengumpulkan informasi yang dapat memudahkan pekerjaan peneliti dan hasil yang diperoleh lebih sistematis, cermat dan lengkap, sehingga lebih mudah di olah. Instrumen yang digunakan dalam penelitian ini adalah lembar observasi keterampilan kognitif dengan dimensi kognitif (1) berpikir simbolik mengenal konsep, (2) belajar pemecahan masalah dan sebab akibat, (3) asosiasi dan klasifikasi. Penilaian keterampilan kognitif menggunakan skala $1-4$.

\section{HASIL DAN PEMBAHASAN}

Sintesis dari beberapa teori mengenai keterampilan kognitif anak usia 5 - 6 tahun antara lain (1) logika dan penalaran logis, analitis, (2) belajar pemecahan masalah dan sebab akibat, (3) meniru dan ingatan, (4) berpikir simbolik mengenai konsep matematika, sains, dan ilmu sosial, (5) asosiasi dan klasifikasi. 
Dimensi keterampilan kognitif yang dapat dikembangkan dalam game calistung digital antara lain (1) belajar pemecahan masalah dan sebab akibat, (2) asosiasi dan klasifikasi, (3) berpikir simbolik mengenai konsep.

Indikator keterampilan kognitif untuk (1) asosiasi dan klasifikasi antara lain, (a) mengidentifikasi objek di tengah, (b) menyusun benda dari kecil ke besar, (c) menunjukkan benda yang lebih besar, (d) memilah objek berdasarkan bentuk dan warna, (e) mengelompokkan objek berdasarkan bentuk dan warna, (f) menempatkan objek dalam urutan atau rangkaian tertentu, (g) mengenai dan membuat pola, (h) menampilkan korespondensi satu satu dengan angka; (2) berpikir simbolik mengenai konsep antara lain (a) menamai 4 warna, (b) memahami jumlah dan ukuran, (c) mengenal sebagian besar warna, (d) mengidentifikasi 8 warna dan namanya, (e) mengidentifikasi bentuk persegi, (f) menghitung 10 benda, (g) menghitung 13 benda, (h) mampu menulis, menjiplak, serta menghitung, (i) akhir usia 6 tahun sudah mulai mampu membaca, menulis, dan berhitung, (j) menghitung sambil menghapal 1-20, (k) Mengenal benda-benda di sekitarnya ( nama, warna, bentuk, ukuran, pola, sifat, suara, tekstur, fungsi dan ciri lainnya); (3) belajar pemecahan masalah dan sebab akibat antara lain (a) menyelesaikan masalah sehari-hari secara kreatif, (b) menyelesaikan soal dengan benda konkret, (c) menyelesaikan masalah dengan program komputer.

Aplikasi game calistung digital diperuntukkan bagi anak anak umur $5-6$ tahun pada taman kanak-kanak. Menu yang ditampilkan mengenal huruf, menulis, berhitung, dan mengenal benda dengan aplikasi menggunakan android.

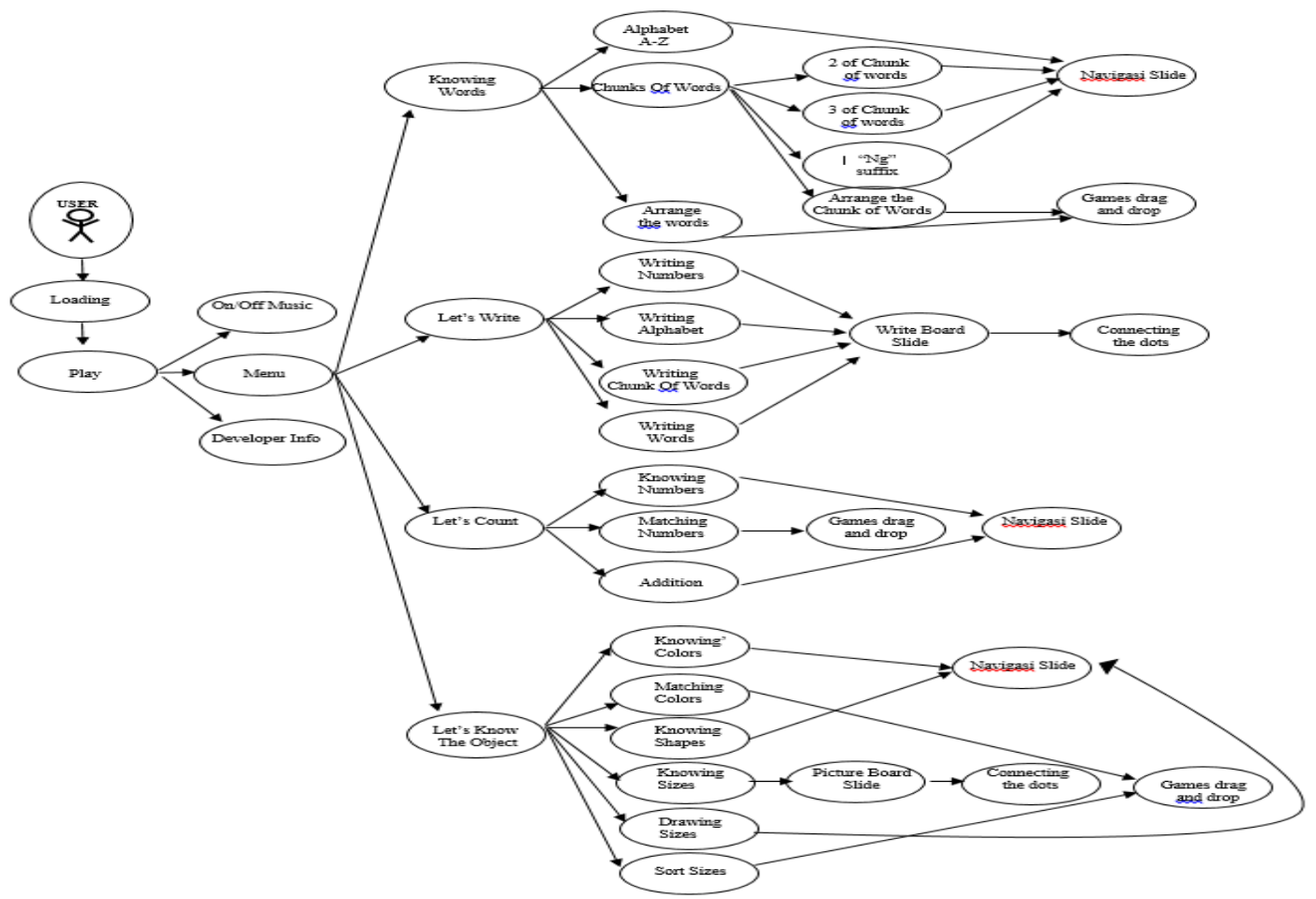

Figure 1. Use Case Diagram of Calistung Digital Games

Data yang di peroleh dari lapangan mengenai tes awal dan tes akhir media pembelajaran game calistung digital dapat dilihat pada tabel di bawah ini. 


\section{Tabel 1. Data Hasil tes Awal dan Tes Akhir Media Pembelajaran Game Calistung Digital}

\begin{tabular}{lcccccc}
\hline Tes & $\begin{array}{c}\text { Jumlah } \\
\text { Siswa }\end{array}$ & \multicolumn{4}{c}{ Media pembelajaran Game Calistung Digital } \\
\hline & & Mean & Varians & $\begin{array}{l}\text { Simpangan } \\
\text { Baku }\end{array}$ & Modus & Median \\
\hline Awal & 26 & 109,19 & 359,04 & 18,95 & 136 & 110,5 \\
\hline Akhir & 26 & 123,88 & 226,35 & 15,04 & 136 & 130,5 \\
\hline
\end{tabular}

Hasil tes awal dan tes akhir media pembelajaran game calistung digital diperoleh dengan data sebagai berikut bahwa hasil tes awal dengan nilai mean 109, 19, varians sebesar 359, 04, simpangan baku sebesar 18, 95, modus sebesar 136 dan media sebesar 110, 5. Sedangkan hasil tes akhir dengan nilai mean 123, 88, varians sebesar 226, 35, simpangan baku sebesar 15, 04, modus sebesar 136 dan media sebesar 130, 5 .

Pemerolehan nilai rata-rata pretest sebesar 109,19 dan pemerolehan nilai rata-rata posttest sebesar 123, 88 sehingga terdapat perbedaan nilai rata-rata sebesar 14,69. Hasil penelitian pada taraf signifikan $5 \%$ dengan derajat kebebasan $(\mathrm{db})=25$, maka didapatkan t-tabel sebesar 1, 75 . Dengan hasil thitung sebesar 6, 81. Sehingga t-hitung lebih besar dari t-tabel (t-hitung > t-tabel), dengan demikian $\mathrm{H} 1$ yang menyatakan bahwa terdapat perbedaan keterampilan kognitif hasil pre dan post siswa taman kanak-kanak: diterima. Dengan demikian hasil penelitian menyimpulkan bahwa media pembelajaran game calistung digital berbasis android dapat meningkatkan keterampilan kognitif anak usia dini.

Hasil penelitian ini sekaligus didukung beberapa penelitian sebelumnya dari penelitian Vanbecelaere mengenai keefektifan game edukasi sehubungan dengan efek kognitif dan nonkognitif (Vanbecelaere et al., 2020). Penelitian Sabri, Mas Idayu Md; Blanchfield, Peter; Hopkins yang mengatakan intervensi berbasis komputer dengan game digital Nessy dibawah pengawasan tepat membantu pembelajaran membaca (Sabri, Mas Idayu Md; Blanchfield, Peter; Hopkins, 2013), permainan puzzle digital yang dirancang secara efektif meningkatkan kemampuan peserta dalam visualisasi spasial dan rotasi mental (Lin \& Chen, 2016), permainan digital sebagai konteks untuk pengembangan kognitif, pembelajaran, dan penelitian perkembangan (Blumberg, Fran C; Fisch, 2013), belajar membaca mengunakan teknologi mobile learning diharapkan dapat membantu anakanak pra-sekolah pada proses pembelajaran khususnya membaca awal (Busran; Fitriyah, 2015), Pengembangan aplikasi perangkat lunak seperti permainan dapat meningkatkan keterampilan kesadaran fonologi terutama membantu akuisi membaca di tingkat TK (Kartal \& Terziyan, 2016). bermain game digital akan meningkatkan pemahaman siswa tentang bilangan rasional (Kiili et al., 2017, p. 320). Dari hasil penelitian mengenai efektifitas game calistung digital dalam mengingkatkan keterampilan kognitif anak usia 5-6 tahun berkaitan erat dengan temuan hasil penelitian game digital dapat meningkatkan motivasi anak karena dalam proses pembelajaran lebih menarik dengan adanya tampilan audio, visual, gambar, dan animasi sehingga anak lebih tertarik dan termotivasi untuk mengenal huruf, mengenal angka, mengenal benda, menulis, dan bermain labirin huruf. Hal ini sejalan dengan hasil penelitian Andreani dan Ying bahwa game pow-pow dapat memotivasi anak untuk belajar kosa kata bahasa Inggris (Andreani \& Ying, 2019, p. 473). Penelitian yang dilakukan Boyle et al., tentang dampak positif dan hasil permainan yang mengambil sampel penelitian periode 2009 hingga 2014, ulasan berfokus pada 143 artikel penelitian yang memberikan bukti kualitas yang lebih tinggi tentang hasil positif dari permainan. Game untuk pembelajaran 
adalah perolehan pengetahuan, sementara game hiburan membahas hasil afektif, perubahan perilaku, persepsi dan kognitif serta fisiologis (Boyle et al., 2016).

\section{SIMPULAN}

Berdasarkan hasil penelitian yang telah dilakukan terhadap siswa pada dua Taman Kanakkanak, maka pemerolehan nilai rata-rata pre-test sebesar 109,19 dan pemerolehan nilai rata-rata post-test sebesar 123, 88. Terdapat perbedaan nilai rata-rata sebesar 14,69. Hasil penelitian pada taraf signifikan $5 \%$ dengan derajat kebebasan $(\mathrm{db})=25$, maka didapatkan t-tabel sebesar 1, 75 . Dengan hasil t-hitung sebesar 6, 81. Sehingga t-hitung lebih besar dari t-tabel (t-hitung > t-tabel), dengan demikian H1 diterima dan Ho ditolak. Dapat disimpulkan bahwa media pembelajaran game calistung digital berbasis android dapat meningkatkan keterampilan kognitif anak usia dini. Untuk kedepan dari kelanjutan hasil penelitian ini maka hal yang dapat dilakukan bahwa perlu dikembangkan media pembelajaran digital untuk meningkatkan perkembangan yang lain seperti seni, motorik kasar dan motorik halus, sosial emosional, nilai agama dan moral. Perlu dikembangkan lebih komprehensif materi keterampilan kognitif yang lebih variatif dan menarik untuk kelanjutan penelitian ini.

\section{REFERENCES}

Allen, K Eileen: Marotz, L. R. (2010). Profil Perkembangan Anak Prakelahiran Hingga usia 12 Tahun (5th ed.). Jakarta, Indonesia: Indeks.

Arikunto, S. (2013). Prosedur Penelitian: Suatu Pendekatan Praktik. Jakarta: Rineka Cipta

Beaty, J. J. (2013). Observing Development of The Young Child, terjemahan: Observasi

Perkembangan Anak Usia Dini. Jakarta, Indonesia: Prenadamedia.

Blumberg, Fran C; Fisch, S. M. (2013). Introduction: Digital Games as a Context for Cognitive Development, Learning, and Development Research. New Directions for Child and Adolescent Development, (139).

Busran; Fitriyah. (2015). Perancangan Permainan (Games) Edukasi Belajar Membaca pada Anak Prasekolah Berbasis Smartphone Android. Jurnal TEKNOIF, 3, 62-70.

Catron, Carol E \& Allen, J. (1999). Early Childhood Curriculum, A Creative Play Model. Columbus: Merril.

Kartal, G., \& Terziyan, T. (2016). Development and evaluation of game-like phonological awareness software for kindergarteners: JerenAli. Journal of Educational Computing Research, 53(4), 519-539. https://doi.org/10.1177/0735633115608397

Kokkalia, Georgia; Economou, Alexandra; Choli, S. (2017). The Use of Serious Games in Preschool Education. IJET, 12(11), 15-27.

Kurniati, A., Tanzil, F., \& Purnomo, F. (2015). Game Development “ Tales of Mamochi " With Role Playing Game Concept Based on Android. Procedia - Procedia Computer Science, 59(Iccsci), 392-399. https://doi.org/10.1016/j.procs.2015.07.549

Lin, C. H., \& Chen, C. M. (2016). Developing spatial visualization and mental rotation with a digital puzzle game at primary school level. Computers in Human Behavior, 57, 23-30. https://doi.org/10.1016/j.chb.2015.12.026

Morrison, George S., D. O. S. R. dan A. W. (2012). Dasar-dasar Pendidikan Anak usia Dini. Jakarta, Indonesia: Indeks.

Morrow, L. M. (1993). Literacy Development in the Early Years: Helping Children Read and Write. USA: Allyn \& Bacon, A Division of Simon \& Schuster, Inc.

Nacher, V., Garcia-sanjuan, F., \& Jaen, J. (2016). Interactive Technologies for Preschool GameBased Instruction : Experiences and Future Challenges. Entertainment Computing. https://doi.org/10.1016/j.entcom.2016.07.001

Nasional, S., \& Informasi, T. (2014). Prosiding Senastik 2014, (September), 10-11. 
Northrop, L., \& Killeen, E. (2013). A framework for using iPADS to build early literacy skills. Reading Teacher, 66(7), 531-537. https://doi.org/10.1002/TRTR.1155

Park, Y. joon. (2013). The Relative Effectiveness of Teacher-made Games for Preschoolers' Understanding Number Concepts. Asia-Pacific Journal of Research in Early Childhood Education, 7, 93-119.

Sabri, Mas Idayu Md; Blanchfield, Peter; Hopkins, G. (2013). The Influence of Digital Games on Learning Reading: A Closer Look. Proceedings of the European Conference on Games Based Learning, 2013, Vol 1p. 730, 1(4), 730.

Santrock, John W Diterjemahkan Oleh Rachmawati, Mila dan Kuswanti, A. (2007). Perkembangan Anak. Jakarta, Indonesia: Erlangga.

Santrock, J. W. diterjemahkan oleh J. D. \& A. C. (2002). Perkembangan Masa Hidup. Jakarta, Indonesia: Erlangga.

Smaldino, Sharon E; Lowther, Deborah L; Russell, J. D. (2012). Instructional Technology \& Media for Learning diterjemahkan oleh Arif Rahman. Jakarta: Kencana Prenada Media Group.

Udjaja, Y., Tanuwijaya, K., \& Kartika, I. (2019). ScienceDirect ScienceDirect The Use of Role Playing Game for Japanese Language Learning. Procedia Computer Science, 157, 298-305. https://doi.org/10.1016/j.procs.2019.08.170 